\title{
Effects of breed and production system on lameness parameters in dairy cattle
}

\author{
L. G. Baird, ${ }^{* 1}$ N. E. O’Connell,† M. A. McCoy, $\ddagger$ T. W. J. Keady, ${ }^{* 2}$ and D. J. Kilpatrick§ \\ ${ }^{*}$ Agri-Food and Biosciences Institute, Agriculture Branch, Hillsborough, BT26 6DR, United Kingdom \\ †Queen's University Belfast, Medical Biology Centre, Lisburn Road, Belfast BT9 7BL, United Kingdom \\ $\ddagger$ Veterinary Service, Department of Agriculture and Rural Development for Northern Ireland, Lurgan, BT67 9JD, United Kingdom \\ §Biometrics Department, Agri-Food and Biosciences Institute, Newforge Lane, Belfast BT9 5PX, United Kingdom
}

\begin{abstract}
The aim of the present study was to assess the effects of Holstein-Friesian (HF) and Norwegian (N) dairy cattle genotypes on lameness parameters in dairy cattle within different production systems over the first 2 lactations. Following calving, HF $(\mathrm{n}=39)$ and $\mathrm{N}(\mathrm{n}=45)$ heifers were allocated to 1 of 3 systems of production (high level of concentrate, low level of concentrate, and grass-based). High- and low-concentrate animals were continuously housed indoors on a rotational system so that they spent similar amounts of time on slatted and solid concrete floors. Animals on the grass treatment grazed from spring to autumn in both years of the study, so that most animals on this treatment grazed from around peak to late lactation. Claw health was recorded in both hind claws of each animal at 4 observation periods during each lactation as follows: 1) -8 to $70 \mathrm{~d}$ postcalving, 2) 71 to $150 \mathrm{~d}$ postcalving, 3) 151 to 225 d postcalving, and 4) 226 to 364 d postcalving. Sole lesions, heel erosion, axial wall deviation, sole length of the right lateral hind claw (claw length), right heel width, and right lateral hind heel height were recorded as well as the presence of digital dermatitis. The $\mathrm{N}$ cows had lower (better) white line and total lesion scores than HF cows. Cows on the high- and lowconcentrate treatments had better sole and total lesion scores than cows on the grass treatment. The HF cows had better locomotion scores than $\mathrm{N}$ cows. Breed and production system differences were observed with respect to claw conformation, including claw length, heel width, and heel height. Digital dermatitis was associated with worse sole lesion scores and interacted with production system to influence white line lesion scores and maximum heel erosion scores. This study shows
\end{abstract}

\footnotetext{
Received May 6, 2008.

Accepted November 17, 2008.

${ }^{1}$ Corresponding author: lorna.baird@afbini.gov.uk

${ }^{2}$ Present address: Teagasc, Research Centre, Athenry, County Galway, Ireland.
}

that genetic, environmental, and infectious factors are associated with hoof pathologies in dairy cows.

Key words: Holstein-Friesian, Norwegian, lameness, claw characteristic

\section{INTRODUCTION}

Lameness is a considerable problem for the dairy industry and is generally regarded as one of the top 3 reasons for culling dairy cattle (Frankena et al., 1992; Kossaibati and Esslemont, 1997). According to LeBlanc et al. (2006), one of the most significant advances in dairy health over the last $25 \mathrm{yr}$ has been the recognition that most dairy health concerns are multifactorial. In light of this, many aspects of dairy production have become scrutinized for their contributions to lameness. Examples include breed, housing, nutrition, and feed management.

The Holstein-Friesian is a popular dairy breed worldwide, traditionally selected for milk production with little emphasis on health traits (Philipsson et al., 1994). The Holstein breed, however, is associated with more health issues than other breeds. For instance, there is an increased probability of clinical mastitis in Holsteins (Washburn et al., 2002) and Holstein-Friesians (Berry et al., 2007) compared with Jersey cows. Moreover, it is commonly believed that Holstein and Holstein-Friesian cattle have more claw health issues compared with other dairy breeds; however, much of the evidence supporting this theory is anecdotal.

Different farm environments (defined as the particular conditions animals experience, incorporating feeding management, diet and housing) influence the performance of production animals (Haskell et al., 2007). Genotype $\times$ environment interactions have been shown to influence milk yield (Cienfuegos-Rivas et al., 1999; Hayes et al., 2003). However, there is an absence of studies that specifically investigate breed $\times$ environment interactions in the lameness literature. Moreover, indoor housing (Singh et al., 1993; Bergsten, 1994; Gitau et al., 1996) and concentrate supplementation (Manson and Leaver, 1988; Livesey et al., 1998) have 
Table 1. Number of animals in each treatment

\begin{tabular}{lcccc}
\hline & \multicolumn{3}{c}{ Production system $^{1}$} & \\
\cline { 2 - 4 } Breed & Grass & High & Low & Total \\
\hline Holstein-Friesian & 13 & 14 & 11 & 38 \\
Norwegian & 18 & 15 & 13 & 46 \\
Total & 31 & 29 & 24 & 84 \\
\hline
\end{tabular}

${ }^{1}$ Grass = grazing animals; high and low $=$ animals housed indoors and fed a high- or low-concentrate diet.

been associated with increased sole lesions and lameness.

The present study is part of an overall comparison of the effects of Holstein-Friesian (HF) and Norwegian (N) genotypes on food intake, animal performance, nutrient utilization, behavior, health, fertility, and longevity (Keady et al., 2001; Crawford, 2002; Keady and Mayne, 2002; Yan et al., 2006). The aim of the current study was to investigate the effect of these breeds on lameness by comparing the claw pathologies and locomotion scores in $\mathrm{HF}$ and $\mathrm{N}$ breeds managed on 3 different production systems.

\section{MATERIALS AND METHODS}

This trial was conducted at the Agri-Food and Biosciences Institute, Hillsborough (formerly the Agricultural Research Institute of Northern Ireland) during 2000 and 2001.

\section{Animals and Treatments}

The study initially involved 104 first-calving dairy cows and followed them through first and second lactation. Fifty-three $\mathrm{HF}$ and $51 \mathrm{~N}$ dairy cattle were selected as in-calf heifers in the Netherlands and Norway, respectively, and were brought to the Agri-Food and Biosciences Institute at least 1 mo before calving. Cows calved between late January and early March in both years of the study (lactation 1: February $16 \pm 11.2$ d; lactation 2: February $24 \pm 23.0 \mathrm{~d}$ ).

Immediately following first calving, $\mathrm{HF}$ and $\mathrm{N}$ animals were allocated to 1 of 3 production systems as follows: 1) a grass-based system with summer grazing $(\mathbf{G}) ; 2$ ) indoor housing with a total mixed diet containing a high proportion of concentrates (HC); and 3) indoor housing with a total mixed diet containing a low proportion of concentrates (LC), as shown in Table 1 . Animals of each breed were blocked into groups of 3 based on calving date, age at calving, BW, BCS, genetic merit, and average milk yield (d 6 to 8 ) postcalving. Within these blocks, animals were then randomly assigned to 1 of the 3 nutritional treatments. Once the animals were allocated to treatment, they remained on the same treatment for both years of the experiment.

\section{Feeding, Housing, and Management}

Diets offered to the 2 breeds were isocaloric and isonitrogenous. During the winter feeding period in both years of the experiment, all animals were loose-housed in cubicle accommodation with free access to water. Each treatment group spent similar amounts of time on slatted floors and on solid concrete floors cleaned by automatic scrapers. The winter feeding regimen for cows on the $\mathrm{HC}$ and $\mathrm{LC}$ treatments is detailed in Table 2. In yr 1 of the experiment animals on the G treatment were offered a $55 \%$ forage diet from calving to turnout. In yr 2 of the experiment the grazing animals were offered a TMR with $9 \mathrm{~kg}$ of concentrates and fresh grass silage.

All diets offered while cows were housed were TMR offered once daily to a $10 \%$ refusal rate. In yr 1, concentrates consisted of $230,225,300$, and $245 \mathrm{~g} / \mathrm{kg}$ fresh weight of barley, wheat, sugar beet pulp, and soybean, respectively. In yr 2, the concentrates consisted of $165,165,295,195,130$, and $50 \mathrm{~g} / \mathrm{kg}$ fresh weight of barley, wheat, sugar beet pulp, soybean, maize gluten, and rapeseed, respectively. The forage offered over the entire study was medium-quality grass silage. Standard vitamin/mineral premixes were also added to the TMR throughout the study.

While at pasture, $\mathrm{G}$ animals were offered 1 and 3 $\mathrm{kg} / \mathrm{d}$ of concentrate twice daily in the milking parlor in lactations 1 and 2, respectively. They grazed from spring to autumn in both years of the study, so that most animals on this treatment grazed from around

Table 2. Nutritional strategies for winter feeding regimens for animals on the high- and low-concentrate diets for indoor-housed animals

\begin{tabular}{lccccc}
\hline & \multicolumn{2}{c}{ High } & & \multicolumn{2}{c}{ Low } \\
\cline { 2 - 3 } \cline { 5 - 6 } Forage proportion in overall diet $(\%)$ & Year 1 & Year 2 & & Year 1 & Year 2 \\
\hline Day 0 to 100 & 40 & 35 & & 70 & 65 \\
Day 101 to 200 & 50 & 45 & & 80 & 75 \\
Day 201 to end of lactation & 50 & 55 & & 80 & 85 \\
\hline
\end{tabular}


Table 3. Sole lesion and heel erosion scoring system (Livesey et al., 1998)

\begin{tabular}{lccc}
\hline & \multicolumn{3}{c}{ Score } \\
\cline { 2 - 4 } Lesion & 1 & 2 & 3 \\
\hline Sole lesion & & Red mark & Hemorrhage \\
Severity & Faint pink mark & $10-50$ & $>50$ \\
Extent, $\%$ & $<10$ & Severe pitting & $10-50$ \\
Heel erosion & Mild pitting & & Corium exposed \\
Severity & $<10$ & & $>50$ \\
Extent, $\%$ & & & \\
\hline
\end{tabular}

peak to late lactation, with approximately 1 wk of partial (night) housing at the beginning and the end of the grazing season. Grass-treatment animals were rotationally grazed using a 1-d paddock system, adjusting the stocking density daily to achieve a residual sward height of approximately $6 \mathrm{~cm}$, measured using a rising plate meter (Ashgrove plate meter, Hamilton, New Zealand). Pathways used by $\mathrm{G}$ cows when moving to and from the parlor were mainly stone/dust lanes with short segments on grass and concrete. The maximum distance from the grazing paddock to the parlor (oneway) was $700 \mathrm{~m}$.

\section{Claw Health/Lameness Observations}

The hind claws of each animal were scored for sole lesions during 4 observation periods in each of the first and second lactations as follows: 1) -8 to $70 \mathrm{~d}$ postcalving; 2) 71 to $150 \mathrm{~d}$ postcalving; 3) 151 to $225 \mathrm{~d}$ postcalving; and 4) 226 to $364 \mathrm{~d}$ postcalving. These observations were carried out approximately every 10 to $14 \mathrm{wk}$. If an animal had more than one observation in a lactation period, the scores for the observations were averaged so that each animal had one score per period.

At each examination the hind claws of each animal were lifted and pared lightly to score lesions on the sole. Sole lesions were scored for severity and extent of the claw affected, using the methodology described by Livesey et al. (1998) (Table 3), scoring each lesion in each zone of the claw (as described by Greenough and Vermunt, 1991). Lesion scores (severity $\times$ extent) over the 6 zones of the sole were added to obtain a cumulative lesion score for the whole claw (zones 1 to 6; total lesion score) and for the sole (zones 4 to 6 ) and white line (zones 1 to 3) separately. Scores for both hind hooves were added so that each animal had one score.

Heel erosion was scored for severity and extent of the claw affected, using the methodology described by Livesey et al. (1998; Table 3). Axial wall deviation ("corkscrew claw") was scored as absent, slight, moder- ate, or severe (Murray et al., 1994). Additional claw measurements were carried out on the right hind claw (for simplicity, because there is no reason to believe the left and right would be different in healthy claws). These measurements included sole length (right lateral claw length), heel width (lateral and medial claws), and lateral heel height.

The presence of digital dermatitis (DD) was scored as absent (score 0), present/mild (score 1), or chronic/ severe (score 2). Position of the lesion was also recorded as heel, interdigital, front, or other. For statistical purposes, the scores for DD were collapsed into 2 categories, present or absent, regardless of where the lesion was identified.

Claws of animals with sole ulcers or other hoof aberrations were correctively trimmed and treated as appropriate during claw health observations and as required. However, no routine claw trimming was performed during the study.

The locomotion of all animals was scored once every 2 wk for the first 8 to 10 wk of lactation and once monthly thereafter, in both lactations. This scoring was performed by one individual throughout the study, using the Manson and Leaver (1988) scoring system on a scale of 1 to 5 . A score of $1=$ minimal abduction/ adduction, no unevenness of gait, no tenderness; a score of $5=$ extreme difficulty in rising, difficulty in walking, adverse effects on behavior pattern. Any animal with a score of 3 or higher was considered clinically lame (score 3 = slight lameness, not affecting behavior).

\section{Statistical Analysis}

Twenty animals ( $15 \mathrm{HF}$ and $5 \mathrm{~N}$ ) had to be removed from the study before second lactation. Eight cows were removed to be used on another study; 1 cow did not recover from milk fever; 11 cows were infertile and therefore were not involved in the second year of the study. For the purposes of this study, only animals with data for both lactations 1 and 2 were included. Thus, the final data set included 84 animals in total: $38 \mathrm{HF}$ and $46 \mathrm{~N}$ dairy cows. 


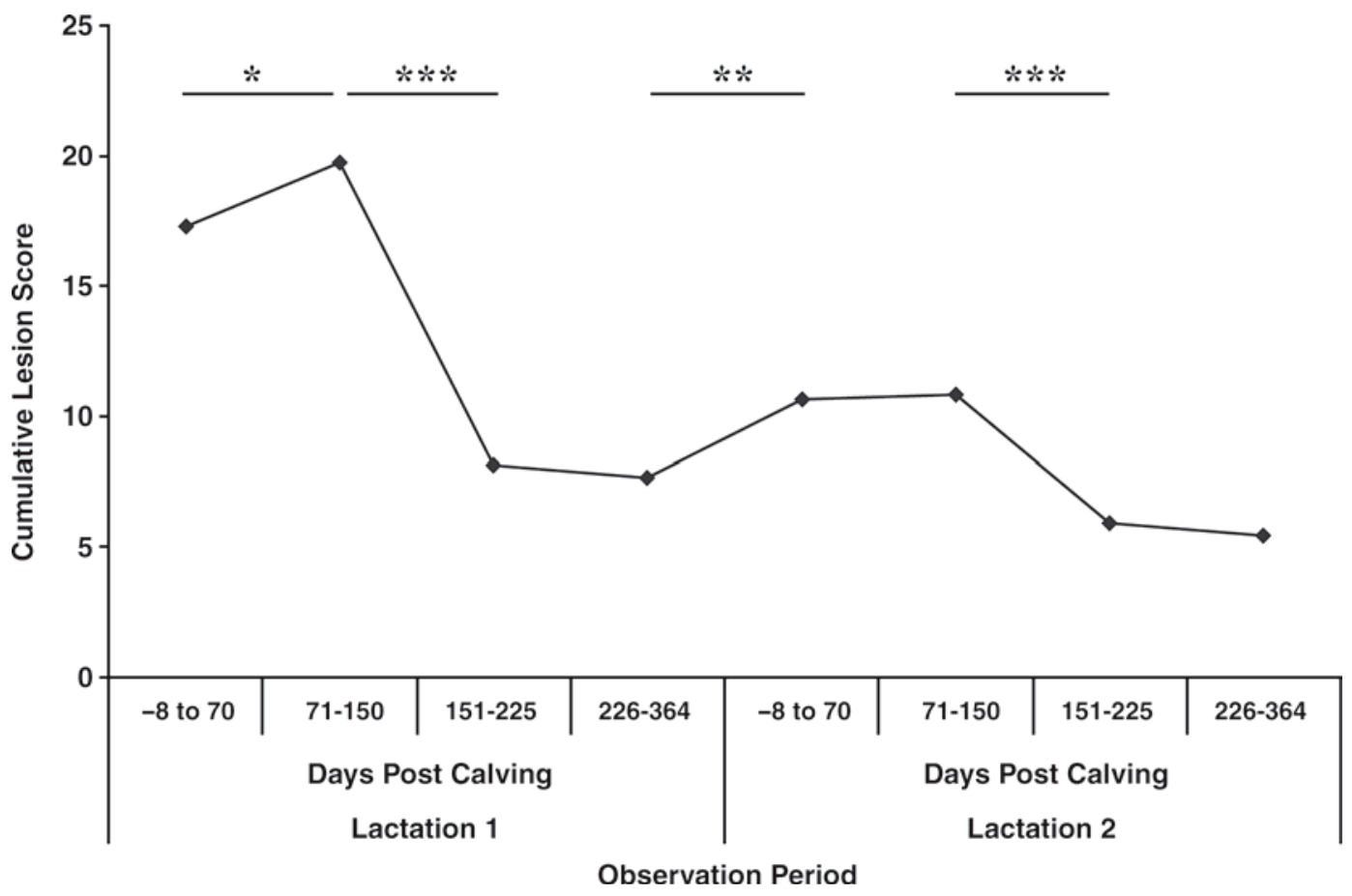

Figure 1. Average total lesion scores (claw zones 1 to 6 ) over the entire study; ${ }^{*} P<0.05 ; * * P<0.01 ; * * * P<0.001$.

Data were analyzed using Genstat 10.1 (Lawes Agricultural Trust, 2007). The total lesion score, and the individual sole and white line lesion scores as well as locomotion scores, maximum heel erosion scores, maximum axial wall deviation scores, right lateral hind claw length, right heel width, and right lateral hind heel height were analyzed using similar models. Each observation was used as a repeated measure in a REML variance components analysis with period during lactation ( 8 periods in total; 4 in each lactation), presence of $\mathrm{DD}$, production system (G, HC, and $\mathrm{LC})$, breed, and 2-way interaction terms as fixed effects. The random term cow $\times$ lactation period was included in the mixed model to account for autocorrelation. It should be noted that the initial blocking of animals served to 1) balance animals over treatments and 2) remove some of the between-animal variation in the statistical analysis. Blocking, however, was not used as a term in the statistical analysis. As such, the analysis is quite conservative in terms of detecting significant differences between treatments.

\section{RESULTS}

\section{Sole Lesions}

General Description of Period Effects. Total lesion scores (claw zones 1 to 6 ) were higher in the first and second observation periods in lactation 1 than in all other periods (Figure 1). In lactation 1 there was an increase in total lesion scores between the first and second observation periods $(P<0.05)$, followed by a decrease from the second to the third observation period $(P<0.001)$ when animals were near mid to late lactation. Total lesion scores increased again from the end of lactation 1 to the observation period at the beginning of lactation $2(P<0.01)$ and decreased again from the second to the third observation period in lactation 2; that is, from peak to mid-lactation $(P<0.001)$. The sole and white line lesion scores followed roughly the same pattern as the total lesion scores.

Treatment Effects. The N cows had lower total and white line lesion scores than the HF genotype $(P<$ 0.05 ; Table 4). There was no difference between the 2 breeds for sole lesion score (claw zones 4 to 6 ).

Production system affected sole $(P<0.05)$ and total lesion $(P<0.05)$ scores. Animals on the $\mathrm{G}$ treatment had higher sole and total lesion scores than the $\mathrm{HC}$ and LC treatment animals $(P<0.05)$. There were no significant interactions between breed and production system on these parameters.

Animals with DD had higher sole (claw zones 4 to 6 ) lesion scores compared with animals without DD $(P<$ $0.05)$. There was a significant interactive effect between production system and the presence of DD on white line lesions $(P<0.05$; Table 5$)$. In animals with no evident DD, cows on the LC treatment had lower white line lesion scores than cows on the $\mathrm{HC}$ and $\mathrm{G}$ treat- 
ments. However, in animals that had DD infections, animals on the HC treatment had the lowest white line lesion scores and those on the $\mathrm{G}$ treatment had the highest white line lesion scores, with animals on the LC treatment being intermediate.

\section{Locomotion Score}

Locomotion scores increased from the onset of the study to the second last observation period in lactation 2 (Figure 2). Table 4 has the effects of treatment factors and DD on locomotion score. The HF genotype had lower locomotion scores than the $\mathrm{N}$ genotype $(P<$ 0.05). Production system did not significantly influence locomotion score $(P>0.05)$. Animals with DD had higher locomotion scores than those without DD $(P<$ $0.001)$.

\section{Heel Erosion}

There was no overall effect of breed on maximum heel erosion scores (Table 4). However, maximum heel erosion scores were affected by an interaction between production system and the presence of DD $(P<0.001$; Table 5). There was no significant difference between maximum heel erosion scores for animals on the 3 production systems that did not show evidence of DD. However, when DD was present, the animals on the G treatment had lower maximum heel erosion scores than animals on the $\mathrm{HC}$ and $\mathrm{LC}$ treatments.

\section{Axial Wall Deviation}

The HF cows had lower maximum axial wall deviation scores than the $\mathrm{N}$ cows $(P<0.001$; Table 4$)$. There was no significant effect of production system, and no significant interactions between any of the factors on maximum axial wall deviation scores.

\section{Claw Length, Heel Width, and Heel Height}

The length of the right lateral hind claw was significantly affected by production system and breed (Table 6). Claw length was greater in the $\mathrm{G}$ and $\mathrm{HC}$ animals compared with the LC animals $(P<0.001)$. The $\mathrm{N}$ animals had longer right lateral hind claws compared with HF animals $(P=0.05)$.

Animals with DD had wider heels than those without DD $(P<0.001)$. There was a relationship between production system and heel width, with animals on the $\mathrm{HC}$ treatment having wider heels than animals on the $\mathrm{G}$ and LC treatments $(P<0.001)$. Breed differences in heel width also occurred ( $\mathrm{HF}<\mathrm{N} ; P<0.05)$. 
Table 5. Least squares means for the effect of interaction between production system and the presence of digital dermatitis on white line lesion score and maximum heel erosion score

\begin{tabular}{|c|c|c|c|c|c|c|}
\hline \multirow[b]{2}{*}{ Lesion score } & \multirow{2}{*}{$\begin{array}{l}\text { Digital } \\
\text { dermatitis }\end{array}$} & \multicolumn{3}{|c|}{ Production system ${ }^{1}$} & \multirow{2}{*}{$\begin{array}{c}\text { Average } \\
\text { SED }^{2}\end{array}$} & \multirow[b]{2}{*}{$P$-value } \\
\hline & & Grass & High & Low & & \\
\hline White line & Present & $5.59^{\mathrm{b}}$ & $4.31^{\mathrm{a}}$ & $5.43^{\mathrm{a}, \mathrm{b}}$ & 0.776 & $<0.05$ \\
\hline Maximum heel erosion & $\begin{array}{l}\text { Absent } \\
\text { Present } \\
\text { Absent }\end{array}$ & $\begin{array}{l}5.69^{\mathrm{b}} \\
1.43^{\mathrm{a}} \\
1.13\end{array}$ & $\begin{array}{l}5.27^{\mathrm{b}} \\
3.07^{\mathrm{b}} \\
1.61\end{array}$ & $\begin{array}{l}3.70^{\mathrm{a}} \\
3.03^{\mathrm{b}} \\
1.3\end{array}$ & 0.305 & $<0.001$ \\
\hline
\end{tabular}

${ }^{\mathrm{a}, \mathrm{b}}$ Means with different superscript letters within the same row (in each section) are significantly different.

${ }^{1}$ Grass $=$ grazing animals; high and low $=$ animals housed indoors and fed a high- or low-concentrate diet.

${ }^{2} \mathrm{SED}=$ standard error of the difference.

There was a breed effect $(\mathrm{N}>\mathrm{HF} ; P<0.05)$ and a production system effect $(\mathrm{HC}>\mathrm{LC}$ and $\mathrm{G} ; P<0.05)$ on heel height.

\section{DISCUSSION}

\section{Breed}

Production System. The N animals on this study showed significantly fewer white line lesions compared with the HF animals. Yan et al. (2006) examined production data from the $\mathrm{HC}$ and $\mathrm{LC}$ treatments discussed here, and found that the HF cows had consistently higher ME intake than N cows. Stone (2004) reported that higher levels of feed intake could contribute to elevated acid production, above the level that salivary buffers can counteract. Researchers have suggested a link between this and subacute ruminal acidosis, which contributes to laminitis and claw pathologies (Cook et al., 2004; Nordlund et al., 2004).

Energy Partitioning and Body Condition. Holstein-Friesian dairy cattle are more efficient at partitioning energy into milk (and not into body tissue) compared with $\mathrm{N}$ cattle (Yan et al., 2006). This, theoretically, could have contributed to the increased lesions in the $\mathrm{HF}$ in the present study. Preferential partitioning of nutrients to support increased milk production in HF cows may result in reduced nutrient availability to repair claw damage or maintain the integrity of supporting structures in the claw, resulting in increased risk of claw damage in HF cows. In a previous review, Webster (1995) concluded that the inability to meet sustained physiological and metabolic demands of lactation in high-yielding dairy cows results in a severe loss of body condition and this may predispose animals to an increased risk of claw lesions and infection.

Boettcher et al. (1998) found that dairy form (which they defined as increased sharpness and decreased BCS), typical of the HF, had a moderately high genetic correlation with clinical lameness. Norwegian cattle are typically shorter and stockier than HF cows, and Yan et al. (2006), who examined data from the HC and LC treatments from the present study, found that the $\mathrm{N}$ animals had consistently higher BCS than the HF cows. This could be another explanation for the lower total and white line lesion scores in the $\mathrm{N}$ cattle. Again, it can be postulated that this is a result of the $\mathrm{N}$ genotype partitioning less energy into milk (experiencing less metabolic stress), and thereby retaining more energy for body reserves (maintenance, growth, and repair) compared with the HF genotype.

Claw Conformation and Claw Quality. Andersson and Lundström (1981) found that HF dairy cows

Table 6. Least squares means for overall breed [Holstein Friesian (HF) and Norwegian (N)], production system, ${ }^{1}$ and digital dermatitis effects on claw characteristics

\begin{tabular}{|c|c|c|c|c|c|c|c|c|c|c|c|c|c|}
\hline Lesion score $^{2}$ & \multicolumn{4}{|c|}{ Breed } & \multicolumn{5}{|c|}{ Production system } & \multicolumn{4}{|c|}{ Digital dermatitis } \\
\hline Heel width $(\mathrm{mm})$ & 105.1 & 106.8 & 0.8 & $<0.05$ & $105.6^{\mathrm{a}}$ & $108.2^{\mathrm{b}}$ & $104.1^{\mathrm{a}}$ & 0.9 & $<0.001$ & 106.7 & 105.3 & 0.5 & $<0.001$ \\
\hline Heel height (mm) & 33.6 & 35.6 & 0.8 & $<0.05$ & $33.8^{\mathrm{a}}$ & $36.2^{\mathrm{b}}$ & $33.8^{\mathrm{a}}$ & 1.0 & $<0.05$ & 35.0 & 34.1 & 0.4 & NS \\
\hline
\end{tabular}

${ }^{\mathrm{a}, \mathrm{b}}$ Means with different superscript letters within the same row (in each section) are significantly different.

${ }^{1}$ Grass = grazing animals; high and low = animals housed indoors and fed a high- or low-concentrate diet.

${ }^{2}$ Claw length $=$ length of the sole of the right lateral hind claw; heel width $=$ width of the right hind hoof; heel height $=$ right lateral hind heel height.

${ }^{3} \mathrm{SED}=$ standard error of the difference. 


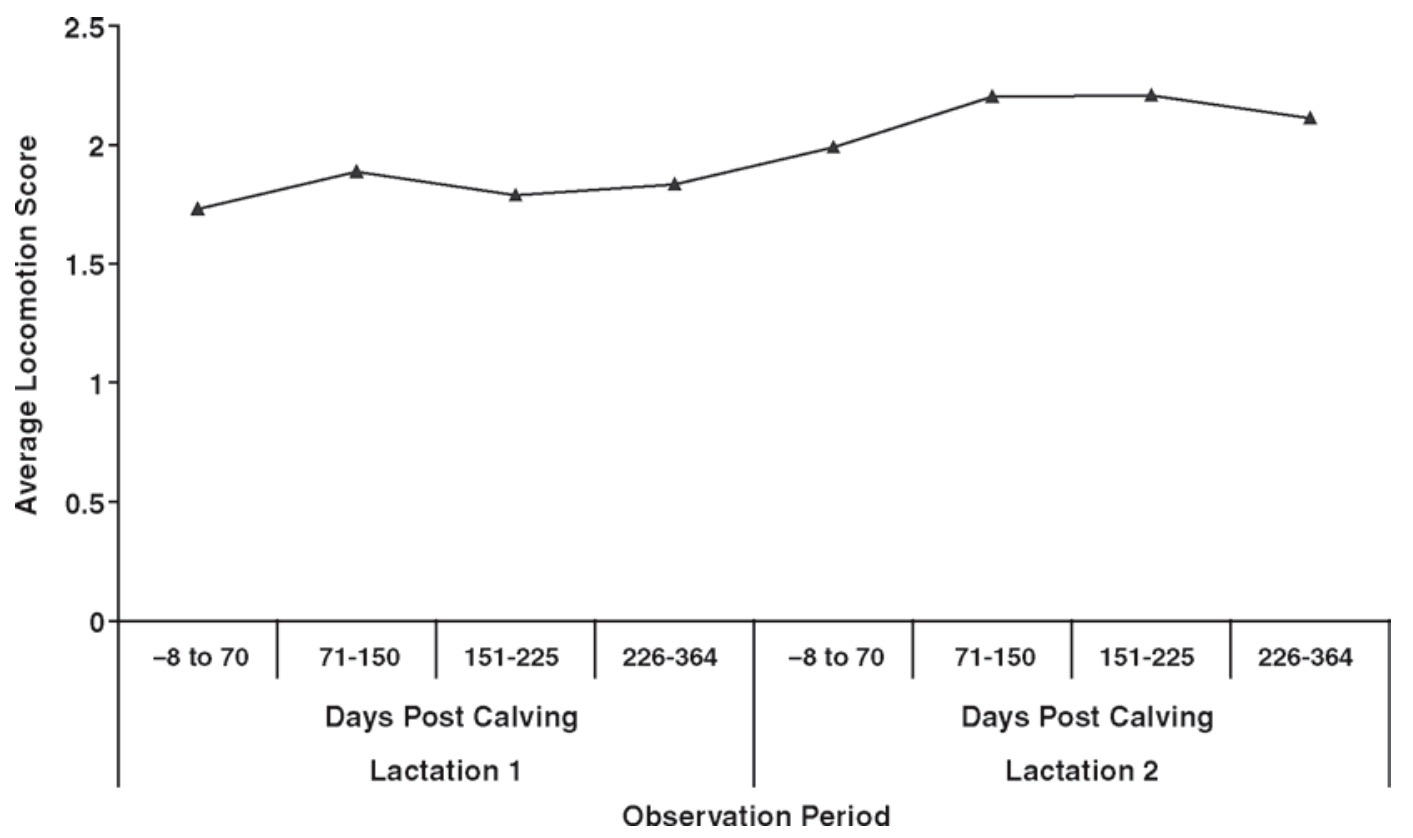

Figure 2. Average locomotion score over the entire study.

were more affected by sole lesions but less affected by claw overgrowth compared with the Swedish Red and White breed. This is supported by results of the present study that found that HF had more claw hemorrhages, whereas the $\mathrm{N}$ genotype had higher scores for axial wall deviation and longer claws.

It was suggested that the lower prevalence of sole lesions in the Swedish Red and White breed was attributed to animals carrying less weight per unit area on their claws compared with the HF (Andersson and Lundström, 1981). Similarly, it is believed that small hooves in relation to body size are a risk factor for lameness in horses (Dyson, 1995). In fact, Distl (1999) established a positive relationship between claw size and the length of productive life in German Holstein cattle. Yan et al. (2006) studied the animals on the HC and LC production systems in the current study and found that genotype had no significant effect on BW, but HF cows were 9 to $10 \mathrm{~kg}$ heavier than $\mathrm{N}$ cows for the whole lactation. Although the $\mathrm{N}$ animals weighed less than their HF counterparts, they had longer, wider claws. This indicates increased surface area of the claw in the $\mathrm{N}$ animals. Less weight per unit area could explain why the $\mathrm{N}$ genotype had fewer claw pathologies (total/white line lesions) than the HF animals.

$D D$. A large number of the $\mathrm{N}$ animals had DD during this study. This was initially considered as an explanation for the $\mathrm{N}$ animals having poorer locomotion scores than the HF (an unexpected result, especially when the claw health data were considered). However, as DD was accounted for in the model predicting locomotion score and there were no significant breed $\times$ DD interactions, it is apparent that the locomotion scores of $\mathrm{N}$ animals were higher regardless of the presence of DD.

Breed Locomotion Score Differences. There is no simple explanation for the consistently higher locomotion scores in the $\mathrm{N}$ genotype compared with the $\mathrm{HF}$ genotype. However, the individual responsible for locomotion scoring the animals on this study would have been accustomed to scoring $\mathrm{HF}$ animals. If the $\mathrm{N}$ animals walk differently (as a breed, compared with HF) this could have biased the scores toward HF animals walking more "normally." In fact, it was noted that in general, the $\mathrm{N}$ animals had more pendulous udders and experienced more edema around calving compared with the HF (our unpublished observation). Although this difference became more substantial in the third lactation and later, it could contribute to the differences in gait seen in this study. White line and total lesion scores were higher in the HF. This means either 1) HF can tolerate poorer claw health without it affecting their locomotion scores or 2) the HF naturally walk differently than the $\mathrm{N}$ animals. If the latter is true, the observer in this study scored $\mathrm{N}$ animals consistently higher, but this does not necessarily reflect poorer claw health in these animals. Consequently, the natural variation in gait between breeds needs to be considered before using locomotion scores to compare different breeds.

\section{Production System}

Gitau et al. (1996) found that cows continuously housed indoors were 3 times more likely to become lame from claw lesions (sole lesions, heel erosion, interdigital 
lesions) compared with cows with access to pasture, a relationship substantiated by numerous other researchers (Somers et al., 2003; Haskell et al., 2006; Onyiro and Brotherstone, 2008). In the present study, the relationship between housing and claw lesions is apparent in only one instance. Digital dermatitis did not affect the heels of the $G$ animals as severely as in the animals under the other 2 production systems. Animals at pasture that had DD had lower maximum heel erosion scores than animals on the indoor treatments with DD. Therefore, it can be concluded that access to pasture decreased the erosive effects of DD on the heels, possibly because the claws of grazing animals are exposed to less manure than claws of indoor-housed cows (Gitau et al., 1996).

Manson and Leaver (1988) reported a higher incidence of lameness in cows fed a high-concentrate diet compared with those fed a low-concentrate diet. The present study did not confirm this as there was no difference in locomotion or lesion score between the $\mathrm{HC}$ and LC diets. Our data are in accordance with those of Gitau et al. (1996) who found no association between supplemental concentrate feeding and lameness.

Concentrate allowance did not appear to be the cause of differences in sole and total lesion scores between the 3 production systems in the present study. Although the LC treatment had the lowest scores for sole and total lesion scores, the $\mathrm{HC}$ treatment was not significantly higher. The $\mathrm{G}$ treatment had significantly higher sole and total lesion scores. This cannot be explained by differences in concentrate allowance as the LC and G treatments were both offered low levels of concentrate supplementation. Two probable factors contributing to the difference between $\mathrm{G}$ and indoor-housed cows were suggested by Laven and Lawrence (2006): cow traffic lane quality and herding management of animals at pasture. Future studies should include a measure of animal handling methods and cow track quality when comparing the effects of different management systems on lameness.

Production system, in combination with the presence of DD, was related to white line lesions. In comparing animals with and without DD, the LC treatment animals with no DD had the lowest white line lesion scores. This could be due to harder claws from the relatively low amount of concentrate in the diet (Manson and Leaver, 1989). However, in animals with DD, the lower concentrate diet did not afford protection from white line lesions.

\section{CONCLUSIONS}

This study shows conclusive evidence that $\mathrm{N}$ cattle have fewer white line lesions than HF. However, the results highlight that nutritional/housing regimens also influence the development of claw pathologies in dairy cows. The increased levels of sole and white line lesions in cattle on the $\mathrm{G}$ compared with the $\mathrm{HC}$ or LC treatments merits further investigation of both nutritional effects and environmental influences (such as cow lane condition) on lameness. Every effort should be made to control the spread of DD in dairy herds for production, health, and welfare reasons. This study shows that DD presence is linked with increased (i.e., worse) claw lesion scores.

Knowledge of the breed differences highlighted in this study could help improve lameness management on farms with either HF or $\mathrm{N}$ dairy cattle. Because of the breed differences in claw length and axial wall deviation demonstrated in this study, the $\mathrm{N}$ genotype appears to require a more proactive claw trimming routine to maintain proper claw shape, irrespective of the housing system. The gait of different breeds may be inherently different, and breed comparison studies must acknowledge this when comparing locomotion scores.

\section{ACKNOWLEDGMENTS}

The authors gratefully acknowledge the staff of the Dairy Unit for data collection and care of the animals, the Biometrics department (Alan Gordon and Sally Dawson) and Andrew Crawford for their contributions. This work was funded by AgriSearch and the Department of Agriculture and Rural Development for Northern Ireland.

\section{REFERENCES}

Andersson, L., and K. Lundström. 1981. Influence of breed, age, bodyweight and season on digital disease and hoof size in dairy cows. Zentbl. Vetmed. Reihe A. 28:141-151.

Bergsten, C. 1994. Haemorrhages of the sole horn of dairy cows as a retrospective indicator of laminitis - An epidemiologic study. Acta Vet. Scand. 35:55-66.

Berry, D. P., J. M. Lee, K. A. Macdonald, K. Stafford, L. Matthews, and J. R. Roche. 2007. Associations among body condition score, body weight, somatic cell count, and clinical mastitis in seasonally calving dairy cattle. J. Dairy Sci. 90:637-648.

Boettcher, P. J., J. C. M. Dekkers, L. D. Warnick, and S. J. Wells. 1998. Genetic analysis of clinical lameness in dairy cattle. J. Dairy Sci. 81:1148-1156.

Cienfuegos-Rivas, E. G., P. A. Oltenacu, R. W. Blake, S. J. Schwager, H. Castillo-Juarez, and F. J. Ruiz. 1999. Interaction between milk yield of Holstein cows in Mexico and the United States. J. Dairy Sci. 82:2218-2223.

Cook, N. B., K. V. Nordlund, and G. R. Oetzel. 2004. Environmental influences on claw horn lesions associated with laminitis and subacute ruminal acidosis in dairy cows. J. Dairy Sci. 87(E Suppl.):E36-E46.

Crawford, A. D. 2002. The effect of breed of dairy cow on oestrus behaviour, fertility and animal performance in a grazing system. PhD Thesis. The Queen's University of Belfast, N. Ireland.

Distl, O. 1999. Breeding for soundness of feet and legs in dairy cattle. Zuchtungskunde 71:446-458. 
Dyson, S. J. 1995. No foot, no horse. Pages 4-8 in Welfare Problems of Food Animals and Horses 1. The Foot Symp. Proc., The Anima Health Trust, BVA Animal Welfare Foundation and RSPCA, Newmarket, UK

Frankena, K., K. A. S. Vankeulen, J. P. Noordhuizen, E. N Noordhuizenstassen, J. Gundelach, D. J. Dejong, and I. Saedt. 1992. A cross-sectional study into prevalence and risk indicators of digital haemorrhages in female dairy calves. Prev. Vet. Med. $14: 1-12$.

Gitau, T., J. J. McDermott, and S. M. Mbiuki. 1996. Prevalence, incidence, and risk factors for lameness in dairy cattle in smallscale farms in Kikuyu Division, Kenya. Prev. Vet. Med. 28:101115 .

Greenough, P. R., and J. J. Vermunt. 1991. Evaluation of subclinical laminitis in a dairy herd and observations on associated nutritional and management factors. Vet. Rec. 128:11-17.

Haskell, M. J., S. Brotherstone, A. B. Lawrence, and I. M. S. White. 2007. Characterization of the dairy farm environment in Great Britain and the effect of the farm environment on cow life span. J. Dairy Sci. 90:5316-5323.

Haskell, M. J., L. J. Rennie, V. A. Bowell, M. J. Bell, and A. B. Lawrence. 2006. Housing system, milk production, and zerograzing effects on lameness and leg injury in dairy cows. J. Dairy Sci. 89:4259-4266.

Hayes, B. J., M. Carrick, P. Bowman, and M. E. Goddard. 2003. Genotype $\times$ environment interaction for milk production of daughters of Australian dairy sires from test-day records. J. Dairy Sci. 86:3736-3744.

Keady, T. W. J., A. D. Crawford, and C. S. Mayne. 2001. A comparison of the Holstein-Friesian and Norwegian cattle breeds for milk production at two levels of nutrient intake. Page 38 in Proc. Br. Soc. Anim. Sci., York. Br. Soc. Anim. Sci., York, UK.

Keady, T. W. J., and C. S. Mayne. 2002. The effect of two levels of nutrient intake on milk production of two dairy cow genotypes. Page 12 in Proc. Br. Soc. Anim. Sci., York. Br. Soc. Anim. Sci., York, UK.

Kossaibati, M. A., and R. J. Esslemont. 1997. The costs of production diseases in dairy herds in England. Vet. J. 154:41-51.

Laven, R. A., and K. R. Lawrence. 2006. An evaluation of the seasonality of veterinary treatments for lameness in UK dairy cattle. J. Dairy Sci. 89:3858-3865.

Lawes Agricultural Trust. 2007. GenStat Release 10.1 reference manual. Oxford Science Publications, Clarendon Press, Oxford, UK.

LeBlanc, S. J., K. D. Lissemore, D. F. Kelton, T. F. Duffield, and K. E. Leslie. 2006. Major advances in disease prevention in dairy cattle. J. Dairy Sci. 89:1267-1279.
Livesey, C. T., T. Harrington, A. M. Johnston, S. A. May, and J. A. Metcalf. 1998. The effect of diet and housing on the development of sole haemorrhages and heel erosions in Holstein heifers. Anim. Sci. 67:9-16.

Manson, F. J., and J. D. Leaver. 1988. The influence of concentrate amount on locomotion and clinical lameness in dairy cattle. Anim. Prod. 47:185-190.

Manson, F. J., and J. D. Leaver. 1989. The effect of concentrate:silage ratio and of hoof trimming on lameness in dairy cattle. Anim. Prod. 49:15-22.

Murray, R. D., D. Y. Downham, J. R. Merritt, W. B. Russell, and F. J. Manson. 1994. Observer variation in field data describing foot shape in dairy cattle. Res. Vet. Sci. 56:265-269.

Nordlund, K. V., N. B. Cook, and G. R. Oetzel. 2004. Investigation strategies for laminitis problem herds. J. Dairy Sci. $87(\mathrm{E}$ Suppl.):E27-E35.

Onyiro, O. M., and S. Brotherstone. 2008. Genetic analysis of locomotion and associated conformation traits of Holstein-Friesian dairy cows managed in different housing systems. J. Dairy Sci. 91:322-328.

Philipsson, J., G. Banos, and T. Arnason. 1994. Present and future uses of selection methodology in dairy cattle. J. Dairy Sci. 77:3252-3261.

Singh, S. S., W. R. Ward, K. Lautenbach, and R. D. Murray. 1993. Behaviour of lame and normal dairy cows in cubicles and in a straw yard. Vet. Rec. 133:204-208.

Somers, J. G. C. J., K. Frankena, E. N. Noordhuizen-Stassen, and J. H. M. Metz. 2003. Prevalence of claw disorders in Dutch dairy cows exposed to several floor systems. J. Dairy Sci. 86:2082-2093.

Stone, W. C. 2004. Nutritional approaches to minimize subacute ruminal acidosis and laminitis in dairy cattle. J. Dairy Sci. 87(F Suppl.):E13-E26.

Washburn, S. P., S. L. White, J. T. Green, and G. A. Benson. 2002. Reproduction, mastitis, and body condition of seasonally calved Holstein and Jersey cows in confinement or pasture systems. J. Dairy Sci. 85:105-111.

Webster, A. J. F. 1995. Welfare considerations in future selection and management. Pages 87-93 in Breeding and Feeding the High Genetic Merit Dairy Cow. T. L. J. Lawrence, F. J. Gordon and A. Carson, ed. British Society of Animal Science Occasional Publication No. 19. Antrim, Northern Ireland.

Yan, T., C. S. Mayne, T. W. J. Keady, and R. E. Agnew. 2006. Effects of dairy cow genotype with two planes of nutrition on energy partitioning between milk and body tissue. J. Dairy Sci. 89:10311042 . 